\title{
ULOGA INTERNE REVIZIJE U NADZORU NAD JAVNIM IZVRŠITELJIMA
}

\section{Saša Stanković}

Telekom Srbija a.d., Beograd Samostalni sektor za zaštitu od fraud-a

\begin{abstract}
Apstrakt:
Polazna osnova ovog rada je pružanje odgovora na pitanje da li je u Komori javnih izvršitelja, čiji članovi obavljaju poslove sa javnim ovlašćenjima ili na osnovu postojeće zakonske regulative, potrebno zakonski regulisati obavezu uvođenja funkcije interne revizije. $\mathrm{U}$ ovom radu ćemo ispitati na koji način nosioci javnih ovlašćenja treba da budu subjekti interne revizije, kao i objasniti razloge zbog kojih se ovo područje ispituje.

Zakonom o izvršenju i obezbeđenju (ZIO, 2011) u pravosudni sistem Srbije uvedena je profesija javnih izvršitelja, kojoj je zakonom dato pravo da u ime države sprovodi izvršenje. S obzirom na važnost sistema prinudne naplate potraživanja sa aspekta obezbeđenja uslova za nesmetano funkcionisanje privrede, i pružanja garancija da se postupak sprovodi u skladu sa Zakonom, važno je uspostaviti adekvatan sistem kontrole nad radom javnih izvršitelja i utvrditi da li su ustanovljeni kontrolni mehanizmi adekvatni sa aspekta zaštite svih učesnika u postupku.
\end{abstract}

Ključne reči:

interna revizija, javni sektor, javni izvršitelji, zakonska regulativa.

UVOD

Profesija javnog izvršitelja podrazumeva javna ovlašćenja koja su u pravosudni sistem Srbije uvedena Zakonom o izvršenju i obezbeđenju (ZIO, 2011). Javni izvršitelji su preuzeli sprovođenje izvršnih postupaka (postupka prinudne naplate potraživanja), umesto sudova. Namirenje novčanih potraživanja nastalih iz komunalnih i srodnih usluga je imperativno prepuštena javnim izvršiteljima, dok su poverioci za sprovođenje ostalih izvršnih postupaka mogli da biraju da li žele da izvršenje sprovede javni izvršitelj ili sud. Novim Zakonom o izvršenju i obezbeđenju (ZIO, 2015) koji je u celosti stupio na snagu od 01.07.2016. godine, javnim izvršiteljima su značajno proširena ovlašćenja.

Troškove izvršnog postupka poverioci predujmljuju javnom izvršitelju u skladu sa Pravilnikom o tarifi o nagradama i naknadama za rad izvršitelja (2012), a od 01.07.2016. godine Javnoizvršiteljskom tarifom (2016). Prihodi koje javni izvršitelji ostvaruju sprovodeći izvršni postupak nekada su bili direktan budžetski prihod sudova, ostvaren na ime takse koju su tarifirali poveriocima u skladu sa Zakonom o sudskim taksama (2011). Pored javnih ovlašćenja, koja su dodeljena javnim izvršiteljima da sprovode izvršenje u ime države, oni svoju delatnost obavljaju kao preduzetnici ili kao ortačka društva. Svaki javni izvršitelj ima svoju kancelariju, svoje zaposlene i svoj sistem organizacije i rada, a u skladu sa čl. 513 (ZIO, 2015) javni izvršioci su članovi Komore javnih izvršitelja.

Komora je organizovana kao neprofitno udruženje sa ovlašćenjima određenim zakonom i statutom Komore, a nadzor nad radom Komore obavlja ministarstvo čl. 522 (ZIO, 2015). Pored niza poslova koje Komora obavlja, čl. 524 (ZIO, 2015) definisano je da vrši i nadzor nad radom javnih izvršitelja. Pored Komore nadzor nad radom javnih izvršitelja sprovodi i Ministarstvo pravde čl. 523 (ZIO, 2015). U najkraćim crtama nadzor se sprovodi sa ciljem utvrđivanja da li je tokom sprovođenja izvršnog postupka postupano u skladu sa zakonom i Javnoizvršiteljskom tarifom (2016).
Korespondencija:

Saša Stanković

e-mail:

sasa.stankovic976@gmail.com 
Postavlja se pitanje na osnovu kojih predviđenih mehanizama bi Komora izvršitelja mogla da se stara o tome da javni izvršitelji sprovode izvršenje u skladu sa zakonom, kao i da li Komora i Ministarstvo mogu da vrše propisani nadzor nad radom javnih izvršitelja najmanje jednom u dve godine ${ }^{1}$. Ovo pitanje posebno dobija na značaju, ako se uzme u obzir da se javni izvršitelji imenuju za nadležnosti viših i privrednih sudova, pa su teritorijalno dislocirani; da je na kraju 2015. godine postupalo 239 javnih izvršitelja koji su u radu imali preko 800.000 predmeta u kojima je na ime troškova tarifirano 9.634.646.074,48 dinara; da su 2015. godine sprovodili izvršenje za potraživanja vredna 105.518.237.748 dinara koje su pravni subjekti i fizička lica potraživali na ime dugovanja; da su javni izvršitelji u skladu sa čl. 500 (ZIO, 2015), sredstva koja naplate tokom sprovođenja izvršenja putem namenskog računa, dužni da bez odlaganja prenesu izvršnom poveriocu; da su 2015. godine javni izvršitelji naplatili 27.975.184.505 dinara za koje bi, na osnovu sistema kontrole, trebalo ustanoviti da li su preneta bez odlaganja (Stanković, 2016).

\section{PRAVILNIK O NADZORU NAD RADOM JAVNIH IZVRŠITELJA}

Kada je u pitanju nadzor nad radom javnih izvršitelja u nadležnosti Komore još uvek je na snazi pravilnik koji je donet u skladu sa prethodnim ZIO (2011). U svakom slučaju, bitno je sagledati princip ustanovljen kroz pravilnik koji se primenjuje kao mehanizam za kontrolu. U skladu sa čl. 347 (ZIO, 2011), kojim je propisana obaveza Komore javnih izvršitelja da vrši nadzor nad radom izvršitelja najmanje jednom godišnje, na osnivačkoj sednici Skupštine Komore javnih izvršitelja Republike Srbije, donet je Pravilnik o nadzoru nad radom izvršitelja i zamenika izvršitelja (2012).

Pravilnik u čl. 2 navodi da nadzor vrši komisija koju formiraju drugi javni izvršitelji, koje imenuje Izvršni odbor Komore javnih izvršitelja, a postoji mogućnost i da se komisija formira od javnih izvršitelja iz pomoćnog imenika javnih izvršitelja.

Član 3 navodi da će Komisija pismenim putem obavestiti kontrolisano lice o datumu i vremenu planirane kontrole. U slučaju da javni izvršitelj koji je predmet kontrole nije u mogućnosti da u predloženom terminu omogući Komisiji uvid u poslovne knjige, evidenciju, spise i uskladištene stvari, dužan je da o razlozima sprečenosti obavesti Komoru u roku od 3 dana, i predloži nov termin.

U slučaju da javni izvršitelj koji je predmet kontrole onemogući Komisiju da vrši nadzor, o takvom postupku Komisija će obavestiti predsednika Komore javnih izvršitelja, a predsednik će o zloupotrebi ovlašćenja, od strane kontrolisanog javnog izvršitelja, obavestiti Ministarstvo pravde.

Članom 4 propisano je da je Komora javnih izvršitelja ovlašćena da naloži otklanjanje uočenih nepravilnosti i pokrene disciplinski postupak.

1 U skladu sa ZIO (“Sl. glasnik RS”, br. 106/15) koji je stupio na snagu 01.07.2016. obaveza vršenja nadzora nad radom javnih izvršitelja je propisana najmanje jednom u dve godine.
Možemo da uočimo da je sistem za nadzor koji je propisan ovim Pravilnikom sistem autokontrole u okviru profesije. Svakako da su sa aspekta zakonitog postupanja javni izvršitelji kompetentni za vršenje nadzora. Međutim, postavlja se pitanje da li javni izvršitelji u postupku nadzora mogu biti objektivni i da li je komisija formirana od drugih javnih izvršitelja adekvatan mehanizam za uspostavljanje efikasnog sistema kontrole? Komisija u postupku nadzora nasumično bira predmete i njihovom proverom donosi zaključak, bez prethodne pripreme za nadzor u okviru koje bi, na osnovu analize rada kancelarije zasnovane na izveštajima ili nekim drugim relevantnim parametrima, formirala uzorak za proveru. Pravilnikom o nadzoru koji je donela Komora nije predviđena odgovornost članova komisije u slučaju ako se neposredno nakon izvršenog nadzora utvrdi nepravilnost u radu izvršitelja, što otvara mogućnost komisiji da ne reaguje kada su u pitanju "manje vidljivi" propusti. S aspekta stručne osposobljenosti za vršenje nadzora, najveća opasnost leži u činjenici da nadzor nad finansijama obavljaju lica koja nemaju adekvatna znanja iz oblasti finansija.

Zbog zakonske obaveze da aktivno sprovodi nadzor Ministarstvo pravde je donelo nov Pravilnik o nadzoru nad radom javnih izvršitelja (Nadzor MP, 2016) kojim se u čl. 2 definiše da nadzor nad radom javnih izvršitelja vrši državni službenik. Pravilnik predviđa da lice ovlašćeno za nadzor ima pravo i dužnost da se stručno usavršava za potrebe nadzora, da bude nepristrasno i nezavisno od bilo čijeg uticaja, te da podatke do kojih je došlo u postupku nadzora mora da čuva kao poslovnu tajnu.

U skladu sa sistematizacijom radnih mesta u Ministarstvu pravde nadzor nad radom javnih izvršitelja je u opisu poslova Odeljenja za pravosudne profesije, koje je deo Sektora za pravosuđe (MP, Pravilnik o unutrašnjem uređenju i sistematizaciji radnih mesta, 2016). U ovom Odeljenju od ukupnog broja zaposlenih, dva diplomirana pravnika su angažovana da pored ostalih poslova vrše nadzor nad radom javnih izvršitelja (Informator o radu MP, 2016), što opet otvara pitanje stručne osposobljenosti za vršenje nadzora u oblasti finansija. Sama činjenica da je donetim pravilnikom propisano da ova lica imaju pravo i dužnost da se stručno usavršavaju za potrebe nadzora, ukazuje da je za nadzor nad radom javnih izvršitelja potrebna stručnost koja prevazilazi potrebe utvrđivanja nepravilnosti samo u oblasti usklađenosti postupanja sa zakonskom regulativom.

Da bismo ustanovili na koji način se tehnički sprovodi nadzor, potrebno je utvrditi koji mehanizmi su predviđeni za vršenje nadzora.

\section{Mehanizmi za sprovođenje nadzora}

Pravilnikom o nadzoru nad radom javnim izvršitelja u čl. 3 (Nadzor MP, 2016) predviđeno je da lice ovlašćeno da vrši nadzor u postupku nadzora ima pravo da:

1) pribavi od stranaka i učesnika u izvršnom postupku i postupku obezbeđenja i predsednika sudova za čije po- 
dručje je javni izvršitelj imenovan, sve podatke o načinu na koji je javni izvršitelj donosio rešenja i zaključke i preduzimao radnje izvršenja i obezbeđenja;

2) zahteva dokumentaciju o visini troškova postupka izvršenja i obezbeđenja;

3) zahteva izveštaje i dokaze o tome kako je javni izvršitelj dostavljao akte sudova i javnog izvršitelja i pismena stranaka i drugih učesnika u postupku;

4) načini uvid u izbor sredstva i predmeta izvršenja i njihove promene u toku postupka izvršenja ili obezbeđenja;

5) zatraži izveštaj o tome da li je i koliko puta ponavljana ista radnja izvršenja ili obezbeđenja;

6) načini uvid u rad kancelarije javnog izvršitelja, radi provere primene Standarda profesionalnog ponašanja javnih izvršitelja;

7) načini uvid u evidenciju o postupcima izvršenja i obezbeđenja i finansijskom poslovanju;

8) pribavi druge podatke koji su potrebni da se odluči o tome da li će se protiv javnog izvršitelja pokrenuti disciplinski postupak.

Članom 6 je predviđeno da lice ovlašćeno za nadzor može na sopstvenu incijativu da pokrene postupak nadzora kada prikupi dovoljno podataka i dokaza koji dovode u sumnju zakonitost ili svrsishodnost rada javnih izvršitelja, koristeći podatke pribavljene uvidom u centralnu bazu podataka, godišnje izveštaje o poslovanju, koji se u skladu sa ZIO (2011, 2015) dostavljaju ministarstvu nadležnom za pravosuđe, etc.

$\mathrm{Na}$ osnovu ova dva člana jasno može da se uoči da u postupku nadzora postoje dva pristupa, jedan po prigovoru kada se postupak nadzora sprovodi uvidom u dokumentaciju predmeta, a drugi pregledom centralne baze podatka i godišnjih izveštaja o radu javnih izvršitelja. S obzirom na veliki broj aktivnih postupaka i imenovanih javnih izvršitelja, i na osnovu podatka da je samo u 2014. godini podneto preko 200 pritužbi stranaka na rad javnih izvršitelja (RTV, 2015), jasno je da dva lica angažovana na poslovima nadzora u Ministarstvu pravde i još dva diplomirana pravnika koja su u Komori javnih izvršitelja angažovana da odgovaraju na pritužbe stranaka u postupku, nisu u mogućnosti da vrše nadzor nad svim aktivnim postupcima. Zato je neophodno utvrditi da li su predviđeni sistemski mehanizmi za vršenje kontrole i nadzora adekvatni?

\section{SISTEMSKI MEHANIZMI ZA NADZOR NAD RADOM JAVNIH IZVRŠITELJA}

Javni izvršitelji imaju obavezu da Komori izvršitelja i ministarstvu nadležnom za poslove pravosuđa podnesu izveštaj o svom radu. Ova obaveza ustanovljena je čl. 502, ZIO (2015). Na osnovu čl. 503, stav 4. ZIO (2015) donet je detaljan akt koji propisuje obrasce i način izveštavanja, Pravilnik o načinu vođenja evidencije o postupcima izvršenja i obezbeđenja i fi- nansijskom poslovanju javnog izvršitelja, načinu izveštavanja i sadržini izveštaja o radu javnog izvršitelja i načinu postupanja sa arhivom (Pravilnik o evidencijama i izveštavanju, 2016).

Ovaj Pravilnik, donet 09.04.2016. godine, je jedan od odgovora nadležnog ministarstva na primedbe i preporuke iznete u „Svebuhvatnoj analizi sistema izvršenja u Srbiji” koju je pripremilo preko 30 domaćih i stranih eksperata u okviru RoLE projekta pod pokroviteljstvom GIZ i EU (Ujdehag et al., 2014).

Od ukupno 14 preporuka iznetih u izveštaju, 4 preporuke su bile direktno povezane sa potrebom za uspostavljenje efikasnijeg sistema za nadzor i kontrolu. Jedna od predloženih preporuka je imala za cilj uvođenje direktne kontrole u oblasti za koju je utvrđeno da je došlo do propusta u odnosu poverilaca (JKP) i javnih izvršitelja, zbog čega je predložena raspodela tzv. komunalnih predmeta preko Komore javnih izvršitelja. $^{2}$

Kada je u pitanju razvoj mehanizama za sistemski nadzor i kontrolu postupaka u trećem poglavlju navedenog izveštaja konstatovano je da je neophodno:

- da se razvije skup profesionalnih strandarda,

- finansijska kontrola,

- spoljni ovlašćeni revizor,

- vanredni nadzor,

- saradnja sa drugim organima,

- razvoj informaciono-tehnoloških rešenja,

- pokazatelji kvaliteta rada.

Cilj preporuke za uvođenje profesionalnih standarda je bio da se obezbedi skup standarda koji su produkt najbolje prakse, i koji izvršitelju omogućavaju profesionalan odnos, nezavisnost i integritet; kao i da se postavi okvir za uvođenje transparetnih kriterijuma na osnovu kojih će se vršiti kontrola, odnosno da se na bazi postavljenih kriterijuma razvije metodologija rada lica ovlašćenih za nadzor.

Finansijska kontrola je navedena kao veoma važan aspekt sistema kontrole, jer javni izvršitelji sredstva naplaćena preko svog namenskog računa treba da prenesu na račun poverioca, bez odlaganja (ZIO, 2011, čl. 329; ZIO, 2015, čl. 500). U preporukama je posebno navedeno da je za ovaj segment kontrole potrebno ustanoviti strožu kontrolu za koju se preporučuje uvođenje sistema revizije (Ujdehag et al., 2014, str. 91). Predlaženo je da javni izvršitelji podnose finansijske izveštaje sa mišljenjem revizora, kao i da ovlašćene računovođe pripremaju izveštaj o ličnom finansijskom stanju javnog izvršitelja.

2 Sve do izmene ZIO (2011) u decembru 2014, diskreciono pravo poverioca je bio izbor javnog izvršitelja kojem će podneti predlog za naplatu potraživanja. Ovakvo zakonsko rešenje je dovelo do toga da su neka JKP podnosila predloge samo određenim javnih izvršiteljima, (na desetine hiljada predloga), bez obzira na vrednost potraživanja, što je dovelo do sumnje u opravdanost pokretanja tako velikog broja izvršnih postupaka kojima je naneta direktna šteta budžetu poverioca. O ovom problemu se dosta pisalo u medijima. Jedan od naslova. http://www.b92.net/info/vesti/index.php?yyyy=2014\&mm=11\&dd=24\&nav_id=928073 
Takođe, u jednoj od preporuka navodi se da bi javni izvršitelji Ministarstvu pravde na svaka tri meseca mogli da podnose izveštaj o novčanim tokovima u okviru kancelarije. Javni izveštaji bi obezbedili informaciju:

- da izvršitelj bez odlaganja prenosi sredstva na račun poverioca,

- da ne postoji nikakav manjak na namenskom računu,

- da izvršitelj ne preduzima nikakve finansijske rizike.

Preporuka za Spoljneg ovlašćenog revizora objašnjena je na način da Komora izvršitelja treba da ovlasti revizore (profesionalnih standarda) i računovođe (finansjiska kontrola) koji bi bili licencirani za vršenje revizije. Komora izvršitelja bi zajedno sa Ministarstvom pravde bila zadužena za redovnu obuku ovlašćenih revizora (Ujdehag et al., 2014, str. 91).

U EU ne postoji ujednačana praksa u zakonodavstvima država članica po pitanju nadzora nad radom pravosudnih profesija. Za unapređenje pravosuđa važnu ulogu ima Evropska komisija za efikasnost pravosuđa CEPEJ, koja je donela niz dokumenata, a jedan od najvažnijih za usaglašavanje pravosudnih sistema je svakako „Vodič najbolje prakse” (CEPEJ, 2009 i 2015), koji svojim preporukama usmeravaju države članice i kandidate u kom pravcu treba da razvijaju najbolju praksu po svim važnim pitanjima. U preporukama "Pravila za sprovođenje aktivnosti nadzora nad radom izvršitelja" (CEPEJ, 2015) u poglavlju 1.2.2.2 navodi se da kada su u pitanju tela koja treba da sprovedu nadzor, države mogu da razmotre mogućnost formiranja nezavisnih adminsitrativnih tela za specijalnim ovlašćenjima čija bi prevashodna uloga bila da vrše superviziju, nadzor i disciplinski postupak kod izvršitelja. Holandija je država koja je otišla najdalje kada je u pitanju nadzor nad finansijskim aspektom poslovanja javnih izvršitelja. Biro za finansijski nadzor vrši nadzor nad računima i registrima u kojima se vode finansijski podaci (Judicial Officers Act, 2001, art. 30) na način da izvršitelji jednom godišnje dostave: izveštaj o poslovanju koji uključuje sve finansijske podatke po svim poslovnim i privatnim računima izvršitelja i članova njihove uže porodice, finansijske podatke o kompanijama u kojima imaju udela, i izjavu o prihodima i troškovima (Judicial Officers Act, 2001, art.17). Izveštaj koji se dostavlja Birou mora da sadrži i zvanično mišljenje revizora o finansijskom poslovanju izvršitelja (Judicial Officers Act, 2001, art. 31).

Iako je u „Svebuhvatnoj analizi sistema izvršenja u Srbiji” (Ujdehag et al., 2014), predloženo slično rešenje za kontrolu finansijskog poslovanja, isto nije prihvaćeno. Jedan od razloga verovatno leži u činjenici da su javni izvršitelji započeli sa radom 2012. godine, a najveći broj je imenovan na ove funkcije 2014. i 2015. godine, pri čemu su na samom početku svog poslovanja bili opterećeni visokim troškovima koji su se u najvećoj meri finansirali iz ličnih izvora. Drugi, važniji razlog, je što bi revizor u skladu sa Zakonom o reviziji (2013) izvršio proveru i ocenu podataka i metoda na osnovu kojih je sastavljen finansijski izveštaj i dao svoje stručno mišljenje o tome da li finansijski izveštaji pružaju istinit prikaz rezultata poslovanja pravnog lica u skladu sa odgovarajućom regulativom za izradu finansijskih izveštaja. To bi bila izuzetna ocena finansijskih kapaciteta javnog izvršitelja, na osnovu koje bi Komora i Ministarstvo pravde dobili pouzdanu informaciju o javnim izvršiteljima koji nisu namenski trošili zarađena sredstva i za koje postoji opravdana bojazan da neće biti u mogućnosti da sprovedu izvršni postupak u predmetima koji su u radu. Međutim, revizor ne bi bio u mogućnosti da samo na osnovu finansijskih podataka utvrdi da li je došlo do prekoračenja ovlašćenja ${ }^{3}$, zbog čega je u samoj preporuci navedeno da Komora treba da bude ovlašćena za izdavanje licence za revizora profesionalnih standarda i finansijske kontrole. S obzirom da ova preporuka nije prihvaćena fokusiraćemo se na preostale preporučene mehanizme.

Da bi se obezbedili tehnički uslovi za uspostavljanje sistema za nadzor i kontrolu u preporukama je navedeno da je potrebno razviti informaciono tehnološko rešenje. Prilikom prikupljanja i analize izveštaja o postupanju javnih izvršitelja, konstatovano je da nije moguće ustanoviti da li je izvršitelj dostavio tačan izveštaj, ako Komora i ministarstvo nemaju direktan pristup bazi podataka. Javni izvršitelji podatke o svom radu vode u softverima kompanija sa kojima javni izvršitelji imaji ugovore, koji im garantuju da su oni vlasnici podatka i da niko sem njih nema prava pristupa podacima. Lične baze podatka, kao što su Excel ili Access baze, pružaju mogućnost prepravljanja podataka bez traga o datumu i vrsti izvršene korekcije. Nepostojanje jedinstvene baze podataka otežava i praktično onemogućava uvođenje sistema kontrole i nadzora. Uvođenjem informaciono-tehnološkog sistema koji Komori i ministarstvu omogućava da pristupe podacima bez intervencije javnog izvršitelja je tehnički osnov za uspostavljanje sistema kontrole.

Pokazatelji kvaliteta rada (Ujdehag et al., 2014, str. 95) se odnose na podatke i obrasce izveštaja o postupanju javnog izvršitelja u skladu sa čl. 348 (ZIO, 2011), i čl. 502 (ZIO, 2015). Predloženo je da se postojeći sistem izveštavanja redizajnira uvođenjem novih obrazaca koji će obuhvatiti transparentno strukturirane podatke koji ukazuju na kvalitet postupanja javnih izvršitelja. Navedeno je da je važno definisati podatke, odnosno ustanoviti metodologiju izrade izveštaja.

U uvodnom delu, kao opšta preporuka navedeno je: „Da bi se pratio kvalitet rada čitavog sistema izvršenja i zbivanja kod svakog pojedinačnog izvršitelja, zakonom ili podzakonskim aktom, treba uvesti obavezu izvršiteljima da kontrolnim organima, tj. Ministarstvu pravde i Komori izvršitelja, redovno u elektronskoj formi obezbeđuju podatke u vezi sa predmetima, kao i finansijske podatke.“(Ujdehag et al., 2014, str. 95). Takođe, važno je da pokazatelji kvaliteta rada budu usklađeni sa CEPEJ smernicama. Da bi se stvorili uslovi za uspostavljanje sistema za nadzor i kontrolu, Ministarstvo pravde je predvidelo kreiranje centralne baze podataka (ZIO

3 Pogledati Rešenje o trajnom prekidu obavljanja delatnosti javnog izvršitelja koje je donelo Ministarstvo pravde protiv javnog izvršitelja Žikice Trajkovića 03.06.2016. br. 740-08-00063/2016-22 
2015, čl. 503, stav 5), za koju je Pravilnikom o evidencijama i izveštavanju (2016) u čl. 3 definisano na koji način će se tehnički uspostaviti. Po pitanju implementacije ostalih preporuka u VI poglavlju istog pravilnika koji se bavi izveštajima o radu javnih izvršitelja, propisani su pokazatelji kvaliteta rada i obrasci koji će omugućiti prikupljanje podataka. Na osnovu prikupljenih podataka Komora i ministarstvo će pratiti na koji način i kojom brzinom se kod svih javnih izvršitelja okončavaju postupci, i biće im omogućeno da prate promet po namenskom računu i ostalim računima javnog izvršitelja.

S obzirom da su date preporuke produkt najbolje međunarodne prakse, stručnjaci koji su ih preporučili nisu pokušali da u važećem zakonodavnom okviru pronađu rešenje, već su ukazali na postajanje uskog grla za koje je potrebno pronaći sistemsko rešenje. Za kontrolne mehanizme koji su prihvaćeni u skladu sa preporukama koje će početi da se realizuju primenom ZIO (2015), tek treba da se dobije odgovor da li su adekvatni. U tom smislu opravdano se postavlja pitanje ko će izvršiti procenu efikasnosti novouvedenog sistema kontrole i izvršiti klasifikaciju i procenu prihvatiljivosti rizika koji preostaju u sistemu izvršenja naplate potraživanja.

\section{ULOGA INTERNE REVIZIJE U PROFESIJI JAVNIH IZVRŠITELJA}

Kada je ustanovljen Insitut javnih izvršitelja država se odrekla direktnog budžetskog prihoda u korist ovih profesija, a njima dala javna ovlašćenja, da u ime države sprovode zakon.

Zakonom o budžetskom sistemu (2015) u čl. 82 definiše se obaveza uspostavljanja interne revizije za sve korisnike javnih sredstava čl. 2 korisnici javnih sredstava su definisani kao: direktni i indirektni korisnici budžetskih sredstava, korisnici sredstava organizacija za obavezno socijalno osiguranje i javna preduzeća osnovana od strane Republike Srbije, odnosno lokalne vlasti, pravna lica osnovana od strane tih javnih preduzeća, pravna lica nad kojima Republika Srbija, odnosno lokalna vlast ima direktnu ili indirektnu kontrolu nad više od $50 \%$ kapitala ili više od $50 \%$ glasova u upravnom odboru, druga pravna lica u kojima javna sredstva čine više od 50\% ukupnih prihoda ostvarenih u prethodnoj poslovnoj godini. Pri čemu se u istom članu javna sredstva definišu kao sredstva na raspolaganju ili pod kontrolom Republike Srbije, lokalne vlasti i organizacija za obavezno socijalno osiguranje.

Prihodi javnih izvršitelja nastaju u izvršnom postupku, u skladu sa pravilnikom koji reguliše tarifu (Tarifa, 2012; Tarifa, 2016). Ono što je nekada bio prihod direktnih budžetskih korisnika sudova, sada je prihod novoformirane pravosudne profesije. Posmatrajući strukturu prihoda javnih izvršitelja na osnovu izveštaja o postupanju javnih izvršitelja za 2015. godinu (Stanković, 2016), uočićemo da 74,63\% prihoda potiče od javno komunalnih preduzeća, čija sredstva su u skladu sa definicijom Zakona o budžetu sredstva na raspolaganju ili pod kontrolom države, a javno komunalna preduzeća u Republici Srbiji su u najvećem procentu u vlasništvu Republike Srbije i lokalnih samouprava (Arsić, 2012).

Tabela 1. Struktura troškova postupka tarifiranih poveriocima u predmetima koji su 2015. godine bili aktivni po vrsti isprava na osnovu kojih se sprovodi izvršenje (Stanković, 2016)

\begin{tabular}{cc}
\hline $\begin{array}{c}\text { Vrste isprava na osnovu kojih } \\
\text { se sprovodi izvršenje }\end{array}$ & $\begin{array}{c}\text { Troškovi } \\
\text { postupka }\end{array}$ \\
\hline $\begin{array}{l}\text { 1. izvršenje na osnovu strane izvršne ili } \\
\text { verodostojne isprave }\end{array}$ & $17.836 .934,00$ \\
\hline
\end{tabular}

2. izvršenje na osnovu domaće izvršne isprave

2.055.351.001,50

3. izvršenje na osnovu domaće verodostojne isprave

$422.821 .467,97$

4. izvršenje za namirenje potraživanja nastalih iz komunalnih i sl. usluga

$7.189 .872 .467,15$

ukupno

$9.634 .646 .074,48$

\% učešće troškova tarifiranih iz stavke 4.

$74,63 \%$

* Ukupan zbir po prikazanim stavkama je 9.685.881.870, 61, razlika je proizvod netačnih zbirova u pojedinim izveštajima javnih izvršitelja. Javni izvršitelji čiji izveštaj sadrži netačan zbir se ne pozivaju po sadašnjem sistemu kontrole i nadzora da objasne razliku.

Ministarstvo pravde koje je nadležno da vrši nadzor nad radom javnih izvršitelja uspostavlja funkciju interne revizije kao direktni korisnik budžetskih sredstava. U Pravilniku o unutrašnjem uređenju i sistematizaciji radnih mesta u Ministarstvu pravde od 28.01.2016. godine, u IX poglavlju čl. 40 navodi se delokrug poslova Odseka za internu reviziju: „Obavlja poslove interne revizije Ministarstva pravde, organa uprave u sastavu Ministarstva i internu reviziju sudova i javnih tužilaštava u skladu sa nadležnošću Ministarstva utvrđenu zakonom koji se odnosi na operativno planiranje, organizovanje i izvršenje zadataka revizije, odnosno testira, analizira i ocenjuje sve poslovne funkcije u skladu sa međunarodnim standardima interne revizije i propisima kojima se uređuje interna revizija u Republici Srbiji.“

U skladu sa čl. 346 (ZIO, 2011) i čl. 523 (ZIO, 2015), nadzor nad zakonitošću rada javnih izvršitelja vrši Ministarstvo pravde, operativno preko Odeljenja za pravosudne profesije, koje je deo Sektora za pravosuđe. U skladu sa definisanim delokrugom Odeljenja za internu reviziju na osnovu kog se u sudovima i tužilaštvima sprovodi revizija u onim oblastima za koje je zakonom utvrđena nadležnost ministarstva, interna revizija bi mogla da vrši i reviziju pravosudnih profesija $\mathrm{u}$ onim područjima u kojima je definisana nadležnost Ministarstva pravde. Odeljenje za internu reviziju Ministarstva pravde: „Vrši proveru primene zakona i poštovanja pravila interne kontrole, ocenu sistema internih kontrola u pogledu adekvatnosti, uspešnosti i potpunosti, reviziju načina rada 
koje predstavljaju ocenu poslovanja i procesa, uključujući i nefinansijske operacije, u cilju ocene ekonomičnost, efikasnosti i uspešnosti." (Informator o radu MP, 2016, čl. 40).

Odeljenje za pravosudne profesije obavlja i posao sačinjavanja godišnjih izveštaja o radu javnih izvršitelja (Informator o radu MP, 2016). S obzirom da je provera tačnosti dostavljenih izveštaja i uparivanje dostavljenih podatka sa podacima koji su u toku godine preuzeti u centralnu bazu podataka deo novouvedenog sistema kontrole i nadzora, a sačinjavanje godišnjih izveštaja je u nadležnosti navedenog Odeljenja, time je ustanovljena još jedna oblast na osnovu koje Odeljenje za internu reviziju treba da vrši reviziju poslovanja javnih izvršitelja, imajući u vidu da bi bilo poželjno da se sa stručnog aspekta izvrši procena novouvedenog sistema kontrole u pogledu adekvatnosti upravljanja rizicima. U tom smislu iz opisa poslova Odseka za internu reviziju možemo da dodamo još jedan argument: „daje savete i stručna mišljenja kada se uvode novi sistemi i procedure.“ (Informator o radu MP, 2016, čl. 40).

Ministarstvo pravde je u cilju uspostavljanja efikasnog sistema kontrole i nadzora, a u skladu sa datim preporukama iz Izveštaja o proceni sistema izvršenja, novim ZIO, predvidelo uvođenje centralne baze podataka koja će biti deo pravosudnog informacionog sistema. U okviru centralne baze podataka prikupljaće se svi podaci o postupanju javnih izvršitelja na dnevnom nivou, zatim standardi profesionalnog ponašanja javnog izvršitelja, novi obrasci i pokazatelji kvaliteta rada u okviru izveštaja o poslovanju. Ipak, ministarstvo nije prihvatilo preporuku o uvođenju revizora koje bi ovlastila Komora i ministarstvo, a koji bi svojom stručnošću garantovali da se proces odvija u skladu sa Zakonom. Bez obzira na tu činjenicu, Odeljenje za internu reviziju Ministarstva pravde, treba da izvrši reviziju novouvedenog sistema kontrole procesa prinudne naplate potraživanja u postupcima pred javnim izvršiteljima, u skladu sa propisanim delokrugom poslova koje obavlja, pružajući nezavisna uveravanja o efikasnosti postavljenih kontrolnih mehanizama, jer će svojom konsultativnom aktivnošću doprineti uspostavljanju sigurnijeg sistema prinudne naplate potraživanja za sve učesnike u postupku. Prilikom planiranja svojih aktivnostiinterna revizija treba da se rukovodi Osnovnim principima profesionalne prakse interne revizije, u kojima se između ostalog navodi da je pronicljiva, proaktivna i usmerena na budućnost.

\section{ZAKLJUČAK}

Profesija javnih izvršitelja je uvedena da bi se uspostavila disciplina i dostigao određeni stepen izvesnosti naplate potraživanja prinudnim putem. Od početka svoga poslovanja javni izvršitelji su preuzeli veliki teret. Oni su sprovodili izvršenje, a da pritom u mnogim aspektima nije postojao sistem koji će pratiti njihov rad i na adekvatan način procenjivati efikasnost njihovog postupanja stoga je svaki izvršitelj stvarao sopstveni sistem evaluacije rada. Ovakva neujadačenost je često prouzrokovala žalbe dužnika na preuveličane troškove, žalbe da sredstva koja su skinuta sa računa dužnika nisu blagovremeno preneta poveriocu, etc. Svi navodi nisu nužno bili namerni propusti, nekada je jednostavno u pitanju bila greška. U ovom radu je postavljeno pitanje na koji način se sprovodi kontrola ovako velikog i složenog sistema koji je od izuzetne važnosti za sigurnost transakcija u privredi, i ko daje uveravanja da su kontrole adekvatne? Naveli smo da je Zakonom o izvršenju i obezbeđenju (2015) propisano da je nadzor nad radom javnih izvršitelja u nadležnosti Ministarstva pravde i Komore javnih izvršitelja, te da je Ministarstvo donelo niz akata kojima je prihvatilo preporuke Izveštaja o proceni sistema izvršenja, za koje se veruje da će uspostaviti efikasniji sistem kontrole.

Preporuka koja nije implementirana odnosi se na uspostavljanje sistema revizije. Međutim, bez obzira što ova preporuka nije primenjena, ukazali smo da postoji pravni osnov po kojem bi Odeljenje za internu reviziju Ministarstva pravde trebalo da izvrši reviziju novouvedenog sistema kontrole nad radom javnih izvršitelja.

S obzirom na značaj delotvornog sistema naplate potraživanja, potrebno je uspostaviti adekvatan sistem kontrole koji će svim učesnicima u postupku garantovati da se postupak sprovodi na najekonomičniji način u skladu sa Zakonom. Efikasnost uspostavljenih sistema kontrole posebno dobija na značaju zbog činjenice da u postupku naplate potraživanja učestvuje veliki broj pravnih lica iz privatnog i državnog sektora i fizičkih lica, te da ovaj proces ima javni značaj. Ocena adekvatnosti uspostavljenih kontrola je visokostručna konsultantska aktivnost koju mogu da sprovedu samo ovlašćeni interni revizori, zbog čega je potrebno da nadležni iz Odeljenja za internu reviziju Ministarstva pravde u plan uvrste i reviziju rada javnih izvršitelja.

\section{LITERATURA}

Arsić, M. (2012). Reforme državnih i društvenih preduzeća, Kvartalni monitor, 28 (januar-mart). Preuzeto 26.06.2016. sa: http://www.fren.org.rs/sites/default/files/qm/L2_5.pdf

Bulletin of Acts, Orders and Decreesof the Kingdom of the Netherlands. (2001). Act of laying down the Judicial Officers.

CEPEJ. (2009). Guidelines for a better implementation of the exsisting council of Europ's recommendation on enforcement. Preuzeto 26.08.2016. sa https://wcd.coe.int/ViewDoc. jsp?p=\&id=1565277\&direct=true

CEPEJ. (2015). Good practice quide on enforcement of judicial decisions. Preuzeto 26.08.2016. sa https://wcd.coe.int/ViewDoc.js $\mathrm{p} ? \mathrm{p}=\&$ Ref $=\mathrm{CEPEJ}(2015) 10$ \&Language $=$ lanEnglish $\&$ Ver $=$ ori ginal $\&$ Site $=$ COE $\&$ BackColorInternet $=$ DBDCF2 $\&$ BackColor Intranet=FDC864\&BackColorLogged=FDC864\&direct $=$ true

Dragović, M. (2015). Sve tužbe na rad izvršitelja odbačene. Preuzeto 30.07.2016 sa http://www.rtv.rs/sr_lat/vojvodina/novi-sad/sve-tuzbe-na-rad-izvrsitelja-odbacene_572936.html. 
Glavčić, N. (2015). Misija i principi. Preuzeto 30.07.2016 sa http:// www.uirs.rs/index.php?option=com_content\&view=categ ory\&id $=83 \&$ Itemid $=20$

Komora javnih izvršitelja. (2012). Pravilnik o nadzoru nad radom izvršitelja i zamenika izvršitelja. Preuzeto 26.06.2016. sa http://www.komoraizvrsitelja.rs/sites/default/files/dokumenti-komore

Ministarstvo pravde. (2016). Informator o radu Ministarstva pravde. Preuzeto 25.07.2016. sa http://www.mpravde.gov.rs/ documents.php?id=60,

Ministarstvo pravde. (2016). Pravilnik o unutrašnjem uređenju i sistematizaciji radnih mesta. Preuzeto 26.08.2016. sa http:// www.mpravde.gov.rs/documents.php?id=60

Službeni glasnik RS. (2014). Zakon o izvršenju i obezbeđenju. „Službeni glasnik RS“ br. 3/2011, 9/2011 - dr. zakon, 109/2013 - US, 55/2014 i 139/2014. Preuzeto 26.08.2016. sa http:// www.paragraf.rs/propisi/zakon_o_izvrsenju_i_obezbedjenju.html

Službeni glasnik RS. (2012). Pravilnik o Tarifi o nagradama i naknadama troškova za rad izvršitelja. „Službeni glasnik RS”, br.50/2012. Preuzeto 26.08.2016. sa http://www.komoraizvrsitelja.rs/?q=propisi/podzakonska-akta/pravilnik-o-tarifio-nagradama-i-naknadama-troskova-za-rad-izvrsitelja-sl

Službeni glasnik RS. (2013). Zakon o reviziji. „Službeni glasnik RS“, br. 62/13. Preuzeto 26.08.2016. sa http://www.paragraf. rs/propisi
Službeni glasnik RS. (2015). Zakon o budžetskom sistemu. „Službeni glasnik RS“, br. 54/09, 73/10, 101/10, 101/11, 93/12, $62 / 13$, ispr 108/13, 142/14, 68/15, - dr. zakon, 103/2015. Preuzeto 26.08.2016. sa http://www.paragraf.rs/propisi/ zakon_o_budzetskom_sistemu

Službeni glasnik RS. (2015). Zakon o izvršenju i obezbeđenju. „Službeni glasnik RS “, br. 106/15. Preuzeto 26.08.2016. sa http://www.paragraf.rs/propisi/zakon_o_izvrsenju_i_obezbedjenju.html

Službeni glasnik RS. (2016). Javnoizvršiteljska tarifa. „Službeni glasnik RS” br. 59/16. Preuzeto 26.08.2016. sa: http://www. paragraf.rs/propisi_download/javnoizvrsiteljska_tarifa.pdf

Službeni glasnik RS. (2016). Pravilnik o nadzoru nad radom izvršitelja. „Službeni glasnik RS“ br.32/2016. Preuzeto 26.06.2016. sa http://www.komoraizvrsitelja.rs/sites/default/files/dokumenti

Stanković. S. (2016). Analiza promena u sistemu izveštavanja o radu javnih izvršitelja $i$ statistika o radu javnih izvršitelja 2012-2015. Beograd: GIZ. Preuzeto 26.08.2016. sa http:// www.komoraizvrsitelja.rs

Ujdehag, J., Ginzburg, S., Popov, K., Bengtson, B., Milošević, M, \& Bodiroga, N. (2014). Sveobuhvatna analiza sistema izvršenja u Srbiji. Beograd: GIZ. Preuzeto 20.07.2016. sa http://www. legalreform.rs/images/NOVAanaliza.pdf

\section{THE ROLE OF INTERNAL AUDIT IN SUPERVISING ENFORCEMENT OFFICERS}

\section{Abstract:}

The starting point of this paper is to provide answers to the question whether it is necessary to legally regulate the obligation to introduce internal audit function in the Chamber of enforcement agents, whose members are engaged in transactions with public authorities, or on the basis of existing legislation to examine how the holders of public authority should be the subjects of internal audit, and explain the reasons why this area is examine.

The judicial system of Serbia Law on Enforcement and Security (ZIO, 2011), introduced the profession of public enforcement agents with rights to carried out the execution in the name of state. Given the importance of the system of enforced collection of receivables from the point of providing conditions for the smooth functioning of the economy as well as providing a guarantee that the procedure is conducted in accordance with the law, it is important to establish an adequate system of control over the work of public enforcement agents, as well as to determine whether established control mechanisms are adequate, from the aspect of the protection of all participants in the process.

\section{Keywords:}

internal audit, public sector, public enforcement agents, legislations. 